\title{
TECHNOLOGY SUPPORT FOR TEACHING MAJORS AT THE UNIVERSITY
}

\author{
УДК 339.13
}

\section{Irina G. Androsova}

PhD in political sciences, the Department of Foreign Languages, Moscow State University of Economics, Statistics and Informatics (MESI)

Tel.: (495) 442-64-98

E-mail: iandrosova@mesi.ru

\section{Tatyana L. Gerasimenko}

Senior Lecturer, the Department of Foreign Languages, Moscow State University of Economics, Statistics and Informatics (MESI)

Tel.: (495) 442-64-98

E-mail: Tgerasimenko@mesi.ru

\section{Evdokiya I. Lobanova,}

$\mathrm{PhD}$ in sociologic sciences, the Department of Foreign Languages, Moscow State University of Economics, Statistics and Informatics (MESI)

Tel.: (495) 442-64-98

E-mail: elobanova@mesi.ru

\section{Alla B. Nisilevich,}

Senior Lecturer, the Department of Foreign Languages, Moscow State University of Economics, Statistics and Informatics (MESI)

Tel.: (495) 442-64-98

E-mail: anisilevich@mesi.ru

\section{Ekaterina V. Strizhova,}

Senior Lecturer, the Department of Foreign Languages, Moscow State University of Economics, Statistics and Informatics (MESI)

Tel.: (495) 442-64-98

E-mail: evstrijova@mesi.ru

This paper aims to show the advantages innovative technologies provide in education. The advent of the technological era has indelibly changed the face of education. When appropriately applied in classrooms, technology affects how instruction is delivered, how students access and process information, and how learning is assessed.

Keywords: multiple technologies, developed confidence, creativity and critical thinking, a collaborative learning environment, video-recording and audio recording capacity.
For current and future foreign language educators to effectively and meaningfully merge technology with instructional practices and activities they must first become adept at using multiple technologies, while simultaneously developing a realistic understanding of the various functions, uses, strengths, and limitations of technology in education settings. A logical starting place for this instruction and training is education programs at the college level. Accordingly, the purposes of this article are (a) to highlight and explain some of the expanding roles and affordances of technology in a collegiate foreign language education program and (b) to encourage continued research and development of instructional technology in teacher education programs.

The role of computer technology in teacher education has yet to be well defined with a proven method for successful integration. However, institutions that prepare future teachers are continually developing ways in which computer technology is embedded into the process of becoming a teacher.

While some programs focus on the integration of technology-enhanced activities (i.e., productivity and professional tools such as PowerPoint or QuickTime), others focus on the integration of hardware (i.e., planning and designing learning environments and experiences such as the inclusion of laptop computers, portable hard drives, cameras, or other peripherals). Neither approach to integrating technology has been proven to be continually successful in preparing teachers to use technology.

1. Introduction Technology helps students acquire knowledge and fluency in a foreign language when web 2.0 tools are used in a collaborative learning environment, promoting learning autonomy and socialization through blogs, wikis and online discussions. (Pellet, 2012) Students may rely on technology in order to review phonetics that are unique to a foreign language. One of the main advantages of using videos, audio, multimedia and mobile based technology when learning a foreign language is having the opportunity to play and repeat phonetics as many times as needed in order to master pronunciation and listening comprehension. Furthermore, when provided appropriate software, students have the opportunity to record their own voice and compare their pronunciation and fluency with that provided by language teachers. Even though technology helps with ear training and fluency in a foreign language, social interaction is also necessary in order to provide opportunities to practice verbal communication. Therefore, integrating technology in a foreign language curriculum, along with social interactions that occur in existing face-to-face foreign language classrooms, may be one of the best resources for foreign language students and teachers. Engage and Empower (2011)acknowledges that technology plays a huge role in the life of the population. An average 18 year old spends an average of 7.3 hours a day using technology. Therefore, the education system should be adjusted to leverage technology to create meaningful learning environments that mirror people's daily lives in the digital age. (Learning: Engage and Empower, 2011) This literature review provides summaries of findings in which foreign language specialists advise to incorporate technology because it helps foreign language learners acquire fluency and improve not only their pronunciation but their listening comprehension as well. The focus of this literature review is to: 1) identify possible effects of technology, both negative and positive of technology when learning a foreign language learning2) review teaching strategies that should be incorporated when technology is used in foreign

2. Identifying the positive outcomes and findings of different online learning studies across the world in order create awareness of which teaching strategies need to be implemented and reinforced can help online teaching be more efficient in helping students succeed. On the other hand, identifying negative aspects can also be an opportunity for teachers and students in order to help them achieve academic success. The literature reviews included in this study bring up 
Ирина Геннадьевна Андросова, доцент кафедры «Иностранных языков» Московского государственного университета экономики, статистики и информатики (МЭСИ)

Тел.: (495) 442-64-98

Эл. почта: iandrosova@mesi.ru

Татьяна Леонидовна Герасименко, ст. преподаватель кафредры «Иностранных языков» Московского государственного университета экономики, статистики и информатики (МЭСИ) Тел.: (495) 442-64-98

Эл. почта: Tgerasimenko@mesi.ru

\section{Евдокия Ивановна Лобанова,} доцент кафредры «Иностранных языков» Московского государственного университета экономики, статистики и информатики (МЭСИ)

Тел.: (495) 442-64-98

Эл. почта: elobanova@mesi.ru

\section{Алла Борисовна Нисилевич,} ст. преподаватель кафедры «Иностранных языков» Московского государственного университета экономики, статистики и информатики (МЭСИ)

Тел.: (495) 442-64-98

Эл. почта: anisilevich@mesi.ru

Екатерина Валентиновна Стрижова ст. преподаватель кафедры «Иностранных языков» Московского государственного университета экономики, статистики и информатики (МЭСИ) Тел.: (495) 442-64-98

Эл. почта: evstrijova@mesi.ru

\section{ТЕХНОЛОГИЧЕСКАЯ ПОДДЕРЖКА} ДЛЯ ОБУЧЕНИЯ В УНИВЕРСИТЕТЕ

Эта статья призвана показать преимущества инновационных технологий представленных в образовании. Приход технологической эры изменил лицо образования. При соответствующем применяется в классах, технологии являются инструкцией по доставке информации и тому как студенты получают доступ и обрабатывают информацию и как обучение оценивается.

Ключевые слова: множественные технологии, развитая доверительные, креативность и критическое мышление, совместная среда обучения, видео - записи и аудио записи емкость . four different topics that need to be taken into account when taking and teaching an online class: a) Socialization through Technology in Foreign Language Learning, b) Ear Training, Comprehension and Pronunciation With Technology, c) Knowledge of Technology when Learning a Foreign Language and d)Integrating Emerging Technologies in the Classroom. Wiki And Digital Video Use In Strategic Interaction-Based Experiential EFL Strategic Interaction (hereafter, SI). $\mathrm{SI}$ is an approach to foreign language instruction that organizes scenarios based on real life events based on experiential learning theory and sociocultural theories of development. SI was incorporated through technology in a foreign language class to thirteen undergraduate students from a public urban Japanese university. According to the findings, English communication skills improved because of workshops that promoted social interaction through technology. Students said that that they preferred language learning through technology over their regular university English classes. In the findings of the study it was discovered that students developed confidence, creativity and critical thinking in each one the SI technology based stages. science and others. However, findings of the study not only reveal that $92.3 \%$ of students agreed or strongly agreed that a lack of support was an issue, but also that they needed more interaction in their online foreign language courses. Students recommended teachers to hold more group classroom and in self-directed study contexts. DeHaan, J., Johnson, N. H., Kondo, T., \& Yoshimura, N. (2012) in Wiki And Digital Video Use In Strategic Interaction-Based Experiential EFL Learning found through the study of 13 voluntary participants from a public Japanese University that their listening comprehension skills improved because of workshop activities delivered through technology, including wikis, videos and so on. Findings also revealed the preference to use technology based social environments over traditional classes because listening comprehension was easier through technology. Since the findings also revealed that students developed confidence, creativity and critical thinking when learning a foreign language through technology based on SI, teachers need to consider implementing mobile technology when technology is not available in a classroom, because modern mobile technology has video-recording and audio recording capacity in addition to incorporating mobile application for foreign language learning. Teachers also acknowledged that online learning requires more modeling and clear explanations from the teachers. $28.3 \%$ of students stated that their teachers were not appropriately prepared to teach an online class. In addition, $36.3 \%$ of students did not agree that their teacher did a good job teaching in an online environment. A student stated that teachers were not able to respond timely through the Blackboard messaging system, since teachers took hours or even days to clarify students' questions. Integrating Emerging Technologies in the Classroom Grgurovic, M. (2011) in Blended Learning In An ESL Class:

3. A Case Study points out that blended learning is one of the most recent advances in educational technology. The study points out that previous research does not deeply describe the positive outcomes and challenges that occur when a blended class is being taught. Findings of the study have the capacity to inform and modify existing teaching models of blended learning, as well as compare the model used with other instructional methods of blended learning. The study investigates a blended model in a listening and speaking English class that used the CALL model as well as the Learning Management System for the first time. Nineteen students from a Intensive English program participated, two from China and two from Korea. A survey was administered in order to assess technology knowledge before the class was delivered. $74 \%$ of students assured that they had previously used computers for English study. Furthermore, the first two lab meetings were used to train students about how to use online materials. One of the strengths was the knowledge of the instructor, since he had been teaching English for 20 years and he described himself as a daily computer user. The instructor used My North Star Lab, using materials that 
were already created, so he did not have to create teaching materials from scratch. My North Star Lab provides teachers the ability to respond orally when providing student feedback using Wimba recorder, a plug-in feature included. When students were in the computer lab, students worked on individual tasks, and the teacher was able to help students not only answering language questions but also technical issues. The teacher was able to focus on students individually, more so that in the traditional classroom. The study found that technology enhanced learning in the foreign language class.

4. The results showed that the use of mobile technology helped to increase the motivation of the learners Active Life, Virtual Worlds and Second life provide multimedia communication features such as audio and virtual 3D realities. The study explains how virtual worlds help second language acquisition. The major findings of the study revealed that Second Language and Active Worlds promoted interaction, motivation and participation. Second Life provided users the opportunity to create a character, which is called Avatar. According to the study, Avatars helped students be more engaged and motivated. The use of Avatars also increased the sense of presence of students in the school environment. Second life offers the option of using real time audio. Furthermore, Second Life also offers multiple communication channels that allow users interact with each other simultaneously, which helped students not only to participate but also to actively interact with other students. Findings also bring up the need for learner and educator training when implementing new technologies in education. Bollen, M., Gaff, J., Jr., \& Goertler, S. (2012) in Students Readiness For And Attitudes Toward Hybrid FL Instruction assess the institutional preparedness for implementing

5. hybrid language classes, focusing on students' computer literacy and access. The study analyzes how students selected hybrid courses not because they were technologically inclined but because of financial and spatial reasons. The findings reveal that the students that did not enroll in hybrid classes showed higher levels of computer literacy and access in comparison with the population that enrolled in hybrid language classes. A survey was given to students who were enrolled in the online of hybrid option and it was found that some students that preferred the hybrid or online option already owned more computer equipment including software, microphones and cameras, but most students lacked enough knowledge to use them.

6. Assessment through computer technology is becoming a fact in educational settings for researchers, teachers and language learners. Almost two decades ago, providers of educational tests introduced computer-versions of proficiency tests for English as a foreign language. At around the same time many institutions began to offer web-based tests for their language courses. These two phenomena have greatly added to the momentum of work in computer-assisted language testing (CALT).

In this presentation we will discuss what CALT is all about: examines its roots, and test types and point out some of the challenges this innovative approach to assessment presents in terms of (a) assessment principles, (b) psychometric and technical issues, (c) the hardware and software used, and (d) administration. Each of these issues will then be discussed in terms of the questions users should ask, and developers must consider when designing L2 computer-mediated tests. Examples of well-known computerized tests will be used to illustrate most of the points discussed.

CALT is no doubt a positive development in assessment practice in many educational contexts as well as in Cyprus, where there is a gap, currently, in scientific research and practice which deals with the development, application and evaluation of modern language assessment practices.

7. Using games to promote learning isn't a new idea. But the widespread use of game-based adaptive learning systems, the explosion of mobile learning applications, and the growing use of game-based strategies makes gamification one of the most important education trends of this decade.

8. According to Teachers College, gamification is the use of game mechanics and dynamics like badges, leader boards, and actions to improve motivation and learning in informal and formal settings. While widespread use of digital learning games and gamebased strategies is relatively new, 8 principles of productive gamification are emerging.

Deeper Learning . "Some innovative game-based and adaptive learning programs embed key elements of performance assessment," said Tim Hudson, Dreambox Learning. "These programs present students with new and unfamiliar situations that require them to engage in critical thinking and strategic problem solving to accomplish challenging and meaningful goals."

Gamification is most common in mathematics about which Mike Flynn, director of Mathematics Leadership Programs at Mount Holyoke College said, "We must give our teachers and students room to explore the area of mathematics so that math is no longer about memorizing procedures, but about developing strong mathematical ideas and understandings that benefit students for life, not just one test."

It's the learning, suggests veteran game designer Raph Koster, is what our favorite games are all about-and we can learn a lot from them about improving education outcomes. Well constructed and applied, learning games and game-based strategies hold the potential to boost motivation, extent persistence, build automaticity, and deepen learning.

1. Conceptual Challenges. Good games incorporate rigorous pedagogy and engaging challenges that promote deeper conceptual learning rather than trivial fact recall. Good games are learning tasks-not entertainment interrupted by a learning quizzes.

Good games are aligned to widely respected standards making it easier to combine with other forms of instruction and assessment and ensure coverage of key concepts. "One of the exciting things that leaps out to me when reading the new Common Core State Standards for mathematics is that the spirit of inquiry and curiosity is back, hardwired into a document that will likely form the basis for mathematics teaching and learning for a long time," said game developer Nigel Nisbet. 
2. Productive Failure. Good games encourage supported failure with instructional feedback. Mental models take lots of practice and feedback to develop. Children learn by creating and testing hypotheses and receiving useful feedback.

3. Careful Calibration. Productive learning systems locate and maintain the zone of proximal development-the gap between what a student knows and what he or she can achieve. Good games are well calibrated-not so easy that they create boredom and not so difficult that they produce frustration.

4. Boosts Persistence. Dr. Jane McGonigal, author, researcher, and game proponent notes that the mindset of gaming-the willingness to fail and keep trying -boosts resilience, persistence, and in and of itself prepares students in the virtual world to deal better with real-world challenges.

Some teachers track team progress on big projects on an interactive whiteboard-an interesting combination of project management tools, a pacing guide, and the competitive effect of a leader board.

5. Builds Confidence. Elizabeth Corcoran, founder of Lucere organization devoted to helping educators find and use the most appropriate technology for inspiring students, notes that one of the main benefits of gamification is that it helps students gain confidence as they learn how to have a winning learning experience, and makes them hungry for tools that put them in control. Good games and game-based strategies build a sense of agency and efficacy.

6. Enhances Intrinsic Motivation. Gamification engages and motivates students while developing problem solving skills and a sense of accomplishment thanks to continuous feed- back and rewards. Cristina Ioana Muntean notes that good games and game-based strategies don't "replace the intrinsic motivation of student, which is stronger and a more long term, with the extrinsic one, but offer a combination of the two for a better performance."

7. Accessibility. In a good game, "every player having equal access to resources and information" and, while progress may vary, "there is a continual opportunity to learn skills to mastery at all levels,"according to teacher Dave Guymon. He added, "Like good game designers, teachers must structure the learning environment and process to offer equal access to the information and resources needed by our students to succeed in learning.

To sum up we should say that smart education is all about future manpowerImplementing systems that specifically cater to each individual's needs and level, which was enabled through overall educational changes as demanded by the 21 st century's knowledge and information-based society. Such examples are the intelligent customized teaching-learning system, educational courses, contents and methods, its evaluation and more. With the advent of digital society, smart education means the transformation of the educational paradigm for the future of our students.

\section{Литература}

1. Герасименко Т.Л., Грубин И.В., Гулая Т.М., Жидкова О.Н., Романова C.A. Smart-технологии (вебинары и социальные сети) в преподавании иностранного языка в неязыковом вузе // Экономика, статистика и информатика. Вестник УМО. 2012. № 5. C. 9-12.

2. Жданова Е.В., Харитонова О.В., Хромов С.С. К вопросу о критериях отбора и оценки веб-ресурсов в преподавании иностранных языков и русского языка как иностранного// Экономика, статистика и информатика. Вестник УМО. 2012. № 3. С. 8-16.

3. Зенина Л.В. Социальный аспект виртуального обучения//Роль бизнеса в трансформации российского общества-2012: сборник материалов Седьмого Международного научного конгресса. М.: Экон-информ, 2012. С. 103-104.

4. Каменева Н.А. Использование информационно-коммуникативных технологий при обучении иностранным языкам // Сборник научных трудов Sworld по материалам международной научно-практической конференции. 2011. Т. 22. № 3. С. 6-8.

5. Каменева Н.А. Развитие творческих способностей студентов высшего профессионального образования//В мире научных открытий. 2010. № 1-2. С. 197-204.

6. Нисилевич А.Б., Стрижова Е.В., Харитонова О.В. Формирование иноязычной коммуникативной компетенции в информационно-обучающей среде вуза и принципы социального конструкцивизма. Экономика, статистика и информатика. Вестник УМО. 2014. № 1. С. 20-22.

7. Нисилевич А.Б., Стрижова Е.В., Харитонова О.В., Каменева H.A. ANOTHER APPROACH TO EDUCATION (ON ALTERNATIVE METHODS OF FOREIGN LANGUAGE TEACHING AND LEARNING) Филологические науки. Вопросы теории и практики. 2013. № 8-1 (26). С. 127-130.

8. Нисилевич А.Б., Стрижова Е.В. Инновационные технологии преподавания в высшей школе. Экономика, статистика и информатика. Вестник УМO. 2013. № 3. С. 3-5. 